\title{
Health Care Professionals' Use of Health Information Systems (HIS) in Indian Hospitals
}

\author{
Mohammed Najimudeen \\ Abdulai \\ Directorate of University Health \\ Services \\ University of Cape Coast (UCC), \\ Cape Coast Ghana
}

\author{
Hassan Faisal Aldheleai \\ Department of Computer Science, \\ Aligarh Muslim University \\ Aligarh, U.P, 202002, India
}

\author{
Mohammed Ubaidullah \\ Bokhari \\ Department of Computer Science, \\ Aligarh Muslim University \\ Aligarh, U.P, 202002, India
}

\begin{abstract}
The need to develop quality Information System (IS) in developing countries has been recognized by international organizations such as the World Bank and World Health Organization (WHO). Health Information Systems (HIS) are expected to have the great impact on health care practices in developing countries in the years to come. On the other hand, the usage of Health Information Systems (HIS) do not seem to get much attention in Africa and third worlds countries.
\end{abstract}

In this research a descriptive survey design and a combination of quantitative and qualitative approaches were employed for this study. Convenient and purposive sampling procedures were employed in two cases studies of Aligarh and New Delhi respectively to obtain Hospitals in India and healthcare professionals respectively for the study. The analysis was based on SPSS and some descriptive statistics. The type of HIS adopted by the case studies was with respect to the demands of the Hospital services and management. It was ascertained that HIS decrease administrative errors, ensures efficiency in healthcare delivery, offer statistical and managerial reports, and up-to-date patient information. Telemedicine procedures were other opportunities observed in the clinical operations of private facilities. Challenges such as large patient attendance, lack of funds, and user perceptions were realized in Government and some private Hospitals. This research was conducted with focus on technical users and managerial in a hospital.

\section{Keywords}

HIS, Health Information System, ISOFT, DHIS2, MEDMANTRA, India, Ghana; Aligarh, New Delhi;Apollo Hospitals, Medanta Hospital.

\section{INTRODUCTION}

The World Health Organization (WHO) has long ago identified Health Information Systems (HIS) as critical for achieving health for all [1], and refers to the concept as an "integrated effort to collect, process, report and use health information and knowledge to influence policy making, programme action and research"[2]. Public, Private, and University Hospitals have made significant investments in adopting and implementing HIS to enhance health care delivery and services in Ghana[3]. Health Information Systems (HIS) are expected to have significant impact on health care practices in the near future[4]. It is evident that the use of modern IT in health care offers remarkable opportunities in reducing clinical errors (e.g. medication errors, diagnostic errors), supporting health care professionals (e.g. availability of timely and up-to-date patients information), increasing the efficiency and effectiveness of care (e.g. patients have to spend less time waiting for treatment), or even improving of patients' health care quality [5].

However, the implementation of HIS in developing countries still encounter some challenges that include; lack of basic infrastructure, cost-effectiveness, technical complexities, lack of experts resources and lack of e- readiness of medical professionals[6]. It is specifically to explore the types of HIS implemented in Indian Hospitals, the background characteristics that influence Healthcare professionals' attitudes towards the use of HIS in Indian hospitals, and the opportunities and challenges on the use of HIS in India. What types of Information System(s) are used in Indian Hospitals in the provision of health services? What are the background characteristics that influence Healthcare professionals' attitudes towards the use of HIS in Indian hospitals? What are some of the revealing opportunities and challenges on the use of HIS in India Hospitals?

Indeed, in a developing country such as Ghana, a research on the development and practical usage of HIS is essential in order to lead policy and administrative decisions and improve the existing systems. This area is perhaps one of the promising, most challenging and most viable fields of research, education, and practice for IS, with significant benefits and outcome for medical informatics and health care in general. In this research two case studies were surveyed the first one was in Aligarh city which considered as a rural area, and the other one was conducted in two hospitals in New Delhi the main city of India. The research covered case study Hospitals form Aligarh City and New Delhi to offer a balance between rural and advanced Hospitals respectively.

This research was sponsored by the Department of Science \& Technology (DST) and Ministry of External Affairs (MEA), Government of India through the Federation of Indian Chambers of Commerce\& Industry (FICCI), under the C V Raman International Fellowship programme for African Researchers. It is to provide Africans the opportunity to conduct collaborative research with leading research groups in Indian Universities and R\&D institutions in areas of Science and Technology.

\section{LITERATURE REVIEW}

The literature review was grouped into three categories as following subsections.

\subsection{Overview of Health Information Systems (HIS) in Developing Countries}

Health information system is simply a "Computer application 
in hospital" [6]. It is referred to as a comprehensive and integrated IS tailored to store, manipulate, retrieve and use information concerned with the management and clinical aspects of a hospital[7]. Third-world many states have been taking on to improve their HIS to assure the availability of related information at all levels of health services, and for local decision-making, planning and management. states such as Tanzania and Kenya have started to act to the challenge [8], with Kenya's establishment of HIS Department that included; computer section, the section of medical records and statistics, and district health management information system (DHIMS) section [9]. The Tanzanian Ministry of Health did implement a Health Management Information System (HMIS) to equip the health sectors in every level with the necessary information in precise time and manner [10].

There are few examples of HIS used in different hospital setups all over the world, and these have been addressed in literature using different terminologies like; Health Management Information Systems (HMIS), Health Information Technologies (HIT), Hospital Information Systems (HIS),Healthcare Information Systems (HIS), Health Information Systems (HIS), Hospital System (HS), and Health Management System (HMS)[11]. The opportunities of using HIS have been well documented, however, a number of implementation challenges have impeded their widespread use in the developing health care settings. These challenges include among others; lack of basic infrastructure, costeffectiveness, technical complexities, lack of experts resources and lack of e- readiness of medical professionals in health care facilities[6].

\subsection{Process of Development of IT based HIS in Ghana}

Based on the current HIS, the Ministry of Health (MOH) via the Ghana Health Services (GHS) and the Centre for Health Information Management (CHIM), have proposed a revised open-source web-based program "DHIS 2" for use by public, private, and semi-government hospitals in Ghana to collect, validate, analysis, and presenting of total statistical data, designed (but not limited) with the aim of activities management of integrated health information. This replaces an old version and improves efficiency and effectiveness in health data management in the country[12]. DHIS2 is an instrument for collection, validation, analysis, and presentation of total statistical data, designed (but not limited) with the aim of activities management of integrated health information. It is a generic gadget instead of a pre-installed database application, with an open meta-data model and a friendly user interface that enable the user to design the contents of a particular information system with no need of programming.

DHIS2 and the later edition is a modular web-based application package with built-in free Java open-source frameworks. DHIS2 is an open-source application introduced under the BSD license which can be used without any charge. DHIS2 can be executed easily at any platform having a Java Runtime Environment (JRE 6 or higher) installed. DHIS 2 is designed and introduced to market by the Health Information Systems Programme (HISP) as an open-source and distributed it worldwide, in current time developers in Tanzania, Vietnam, Ireland, Norway and India are working on it. The development is organized by Oslo University, still, the core support is from Norad (Norad is the Norwegian Agency for Development Cooperation) [13]. As of October 2012, the DHIS 2 is installed in over 30 countries like Ghana, Kenya, Uganda, Tanzania, Rwanda, Bangladesh and Liberia, many more countries in South America, Africa and Asia have also implemented DHIS 2 as their back-bone health care software. [12], and there are continuous increasing of states deploying DHIS 2.

\subsection{Telemedicine}

Telemedicine, a term was made in the 1970s, which accurately means "healing at a distance" [14], patients improvement outcome reflect the employ of ICT to better access to the health care and medical information. It is the "the delivery of health care services, where distance is the crucial element, by whole health care experts using information and communication technologies for the swapping of valid information for disease's diagnosis, curing and prevention of illnesses and injuries, research and evaluation, and for the continuing education of all healthcare providers, are in the interest of advancing the health of individuals and their communities" [15]. Telemedicine is also regarded as the employment of electronic communication and information technologies to provide or support clinical care at a distance [16]. A key concept in this definition is the distance between the participants, a factor that makes this technology especially useful in rural settings. These systems reflect one mode of connecting urban concentricity of physicians with widely scattered groups of rural patients and their caregivers.

Technological developments and price reductions in both computing and communications equipment and transportation fees have made the use of these tools more rewarding[17]. On November 8, 2013, the Apollo Hospitals Group (India) and the Country Hospitals Group (Kumasi, Ghana) launched a telemedicine facility at Abenkyiman Hospital in Anhwiankwanta in Bekwai Municipality. Telemedicine, by which the finest healthcare is brought to all via experienced and highly trained physicians by using ICT, provides clinical health care from a distance and can improve access to medical services that would not often be continuously available in the remote regions and provincial communities. Telemedicine also plays a very crucial in lives saving in the emergences and critical cases.

\section{RESEARCH METHODS}

The research methods were conducted in four stages as following.

\subsection{Research Design}

A mixed set of quantitative and qualitative approaches were used for this study, a descriptive survey design was used to collect the data needed to answer the research questions, and survey of several hospitals in India was conducted to recognize and classify opportunities and challenges in the use of HIS, so the researchers studied two cases of different conditions and location to understand the frequency of use of HIS techniques in Indian hospitals. The study was descriptive because it emphasized the in-depth description of the attitude of Healthcare professionals towards HIS. The study collected in-depth description of the types of HIS used, as well as related opportunities and challenges. Quantitatively, a semistructured questionnaire instrument was used to capture data for the process. The research also focused on the use of qualitative data like interviews, documents, and participant observation data, to understand and explain the usage of HIS and for case findings.

\subsection{Study Population and Sampling Strategy}

The study population included healthcare professionals in the 
two case studies at post at the time of data collection at the Indian hospitals located in different areas, where the first case study was in the rural regions and the second one was in the capital city of India (New Delhi). The target population was purposively users of HIS in any hospital visited; technicians and managers who were directly involved in the use of hospitals system. This was due to the assumption that they were freed from bias in telling about the HIS system used in their facility. The exclusion criteria were on health professionals whose work procedures had no link at all to the usage or management of the HIS in the facility during the study period. Accidental sampling procedure; which is a nonprobability sampling technique, was employed in locating Hospitals in U.P(Uttar Pradesh) state to obtain data. Purposive sampling technique which is also a non-probability sampling method was employed in the attainment of twenty (20) health care professionals, who were technicians and management staff and directly connected with the usage of HIS in their facilities. Sampling size in this study depended mainly on what could be done with available time and resources, and the exclusion criteria as far as the usage of the HIS were concerned.

\subsection{Data Collection Instrument and Method}

The data collection instrument employed for this study is a questionnaire. It consisted of questions to identify and measure healthcare professionals' views on the opportunities and challenges of the use of HIS in health care delivery and services. The questionnaire instrument (Appendix A) contained four (4) parts; which included socio-demographic characteristics and professional background (Part I), HIS system (Part II), Opportunities and Challenges of HIS Usage (Part III), and General Comments (Part IV). Only questions in part IV captured responses via a five-points Likert scale with answers ranging from "Strongly Disagree (SD)" to "Strongly Agree (SA)".

\subsection{Mode of Analysis}

Data was finally organized and processed using an IBM software SPSS (Statistical Package for Social Scientists) and strict guidance by my supervisor. Descriptive statistics including frequency tables, simple percentages, measures of central direction and dispersions were also considered.

\section{RESEARCH FINDINGS AND DISCUSSIONS}

The research findings were grouped into six sections as following.

\subsection{The Case of Aligarh Hospitals}

The city of Aligarh is an administrative town of the northern state of U.P, and away from Kanpur city about $291 \mathrm{~km}$ northwest. It is distinguished for being the seat of the AMU, a host University of this research study. A researcher visited a number of notable Aligarh Hospitals to ascertain the usage of HIS in the provision of health care services and management. These Hospitals included J.N. Medical College, Firoz Specialist Hospital, Mithraj Hospital Aligarh, and the Aligarh University Health Services.

Despite India's ascendancy as the hub of Information Technology (IT) and IT-enabled services industry equipped by a vast pool of skilled manpower, some renowned Hospitals like those visited in Aligarh still lagged tremendously behind in the adoption of HIS in health care delivery. The J.N. Medical College; which records an average of about 500,000 outpatients and 55,000 in-patients annually boast of medically related equipment in health care delivery. However, the College still apply paper based records keeping procedures without a modern software to aid their activities in health care delivery. Challenges such as large patient size, low computer literacy among the government staff, and lack of institutional initiative and government support leaves the largest Hospital in Aligarh without a modern IT systems for health care delivery. Firoz Specialist Hospital and Mithraj Hospital Aligarh are private Hospitals with modern medical equipments, but without HIS systems for health care delivery. The University Health Services is at the heart of the Aligarh Muslim University, and responsible for the health care of students, staff and the University Community. The facility also lacks modern HIS to enhance health care delivery and data analysis. These findings are consistent with [6], that certain countries like India still encounter some challenges that include; lack of infrastructure, cost, technical sophistications, lack of skilled human resources and lack of ereadiness of medical professionals.

\subsection{The Case of New Delhi Hospitals}

Due to the unavailability of modern HIS in Aligarh Hospitals, a number of Hospitals in Delhi were recommended and approved by my supervisor for further exploration on the use of HIS. The Hospitals included; Indraprastha Apollo Hospitals, Medanta Hospital, Max Hospital and AIIMS. The questionnaire instrument was administered on staff of these Hospitals to explore some experiences with the systems used in health care delivery. The following is an analysis of the findings related to the usage of the HIS in Apollo Hospitals and Medanta Hospitals, where ten (10) questionnaires each were administered on health professionals in those facilities. Time constraints defeated the earlier objective of administering questionnaire on Max Hospital and AIIMS staff.

\subsubsection{Type of HIS Used at Hospitals}

The research mainly concentrated on the Medical Records, Registration points or the IT Units of the case Hospitals. As indicated in the introduction of the research, there are various types of HIS used worldwide as health management information system tools in the health care industry, and the Hospitals in Delhi were not an exception. Health care professionals in Apollo and Medanta hospitals used different types of HIS as health management information system.

As indicated in table 1, Apollo Hospitals use a system called "MEDMANTRA" https://www.medmantra.com/[18], whiles Medanta Hospital employs "ISOFT" as their HIS for health care delivery. These e-health systems are installed and extensively used by all Units/Sections/Departments in both Hospitals. MEDMANTRA and ISOFT are electronic health systems built with the goal of enabling physicians and caregivers to employ technology for better care delivery. According to the users, these HIS are Computer-based Patient Record (CPR) solution systems for storing, managing and retrieving patient/clinical history/information, and further used for the management of pharmacies and stores. They allow patients or clients to have a single electronic medical record that contains every piece of clinical information ever collected throughout their lifetime in the hospital. At the 
Table 1. Distribution of HIS and Hospital

\begin{tabular}{|c|c|c|c|c|c|}
\hline & \multicolumn{2}{|c|}{ HOSPITAL } & \multirow[b]{2}{*}{ Total } \\
\hline & & & MEDANTA HOSPITAL & APOLLO HOSPITAL & \\
\hline \multirow[t]{4}{*}{ HIS Name } & ISOFT & Count & 10 & 0 & 10 \\
\hline & & $\%$ of Total & $50.0 \%$ & $.0 \%$ & $50.0 \%$ \\
\hline & MEDMANTRA & Count & 0 & 10 & 10 \\
\hline & & $\%$ of Total & $.0 \%$ & $50.0 \%$ & $50.0 \%$ \\
\hline \multirow[t]{2}{*}{ Total } & & Count & 10 & 10 & 20 \\
\hline & & $\%$ of Total & $50.0 \%$ & $50.0 \%$ & $100.0 \%$ \\
\hline \multirow[t]{2}{*}{ Web Based } & YES & Count & 10 & 9 & 19 \\
\hline & & $\%$ of Total & $52.6 \%$ & $47.4 \%$ & $100.0 \%$ \\
\hline \multirow[t]{2}{*}{ Total } & & Count & 10 & 9 & 19 \\
\hline & & $\%$ of Total & $52.6 \%$ & $47.4 \%$ & $100.0 \%$ \\
\hline \multirow[t]{4}{*}{ Stats Analysis } & YES & Count & 8 & 9 & 17 \\
\hline & & $\%$ of Total & $44.4 \%$ & $50.0 \%$ & $94.4 \%$ \\
\hline & $\mathrm{NO}$ & Count & 1 & 0 & 1 \\
\hline & & $\%$ of Total & $5.6 \%$ & $.0 \%$ & $5.6 \%$ \\
\hline \multirow[t]{2}{*}{ Total } & & Count & 9 & 9 & 18 \\
\hline & & $\%$ of Total & $\mathbf{5 0 . 0 \%}$ & $50.0 \%$ & $100.0 \%$ \\
\hline \multirow[t]{2}{*}{ Patient Records } & YES & Count & 10 & 9 & 19 \\
\hline & & $\%$ of Total & $52.6 \%$ & $47.4 \%$ & $100.0 \%$ \\
\hline \multirow[t]{2}{*}{ Total } & & Count & 10 & 9 & 19 \\
\hline & & $\%$ of Total & $52.6 \%$ & $47.4 \%$ & $100.0 \%$ \\
\hline \multirow{2}{*}{\multicolumn{2}{|c|}{ Diagnosis Details YES }} & Count & 10 & 9 & 19 \\
\hline & & $\%$ of Total & $52.6 \%$ & $47.4 \%$ & $100.0 \%$ \\
\hline \multirow{2}{*}{\multicolumn{2}{|c|}{ Total }} & Count & 10 & 9 & 19 \\
\hline & & $\%$ of Total & $52.6 \%$ & $47.4 \%$ & $100.0 \%$ \\
\hline
\end{tabular}

International registration lounge of Apollo Hospitals, the orientation offered on how "MEDMANTRA" is used in registration of international patients on arrival. As evidential in table 1, majority of the Health care professionals from both Hospitals describe MEDMANTRA and ISOFT as web based software that store patient records and diagnosis for life, and also offer statistical analysis for decision making. Majority of the respondents from Medanta (27.8\%) and Apollo Hospitals
(33.3\%) most often learn the usage of the HIS through organizational training. Other respondents from Medanta Hospital learn the usage of the HIS by self $(11.1 \%)$ and sometimes a combination of both methods $(11.1 \%)$. The other respondents from Apollo Hospitals (16.7\%) also learn the usage of their system by both methods as explained in tables 2 and 3.

Table 2. Best form of learning and Influential Attitude on HIS usage

\begin{tabular}{|c|c|c|c|c|c|c|c|c|}
\hline & \multicolumn{2}{|c|}{ Training } & \multicolumn{2}{c|}{ Myself } & \multicolumn{2}{|c|}{ Both } & \multicolumn{2}{c|}{ Total } \\
\cline { 2 - 9 } & Count & $\%$ of Total & Count & $\%$ of Total & Count & $\%$ of Total & Count & $\%$ of Total \\
\hline How do you learn best? & 11 & $61.1 \%$ & 2 & $11.1 \%$ & 5 & $27.8 \%$ & 18 & $100 \%$ \\
\hline
\end{tabular}

Table 3. Best form of learning and Influential Attitude on HIS usage

\begin{tabular}{|c|c|c|c|c|c|c|c|c|c|c|c|c|}
\hline & \multicolumn{2}{|c|}{$\begin{array}{c}\text { Errors } \\
\text { reduction }\end{array}$} & \multicolumn{2}{|c|}{ Efficiency } & \multicolumn{2}{c|}{$\begin{array}{c}\text { Perceived Ease } \\
\text { Of Use }\end{array}$} & \multicolumn{2}{c|}{$\begin{array}{c}\text { Perceived } \\
\text { Usefulness }\end{array}$} & \multicolumn{2}{c|}{ User Friendly } & \multicolumn{2}{c|}{ Total } \\
\cline { 2 - 12 } & Count & $\begin{array}{c}\% \text { of } \\
\text { Total }\end{array}$ & Count & $\begin{array}{c}\% \text { of } \\
\text { Total }\end{array}$ & Count & $\begin{array}{c}\% \text { of } \\
\text { Total }\end{array}$ & Count & $\begin{array}{c}\% \text { of } \\
\text { Total }\end{array}$ & Count & $\begin{array}{c}\% \text { of } \\
\text { Total }\end{array}$ & Count & $\begin{array}{c}\% \text { of } \\
\text { Total }\end{array}$ \\
\hline $\begin{array}{c}\text { What best } \\
\text { influence your } \\
\text { attitudes towards } \\
\text { the use of his in } \\
\text { the hospital? }\end{array}$ & 10 & $50.0 \%$ & 3 & $15.0 \%$ & 2 & $10.0 \%$ & 3 & $15.0 \%$ & 2 & $10.0 \%$ & 20 & $100 \%$ \\
\hline
\end{tabular}




\subsubsection{Opportunities of HIS Usage}

The questionnaire instrument provided four (4) items to ascertain the opportunities regarding the usage of HIS by the health care professionals under study. Majority of respondents from both Medanta (35\%) and Apollo (35.0\%) Hospitals strongly agree that HIS increases administrative and healthcare efficiency. Respondents generally agreed to all items suggesting opportunities for the use of the various systems in their facilities, as indicated in table 4.

Table 4: Opportunities of HIS Usage

\begin{tabular}{|c|c|c|c|c|c|c|c|c|c|c|c|c|}
\hline & \multicolumn{2}{|c|}{$\begin{array}{c}\text { STRONGLY } \\
\text { AGREE }\end{array}$} & \multicolumn{2}{|c|}{ AGREE } & \multicolumn{2}{|c|}{ Neutral } & \multicolumn{2}{|c|}{ Disagree } & \multicolumn{2}{|c|}{$\begin{array}{l}\text { Strongly } \\
\text { Disagree }\end{array}$} & \multicolumn{2}{|c|}{ Total } \\
\hline & Count & $\begin{array}{l}\% \text { of } \\
\text { Total }\end{array}$ & Count & $\begin{array}{l}\% \text { of } \\
\text { Total }\end{array}$ & Count & $\begin{array}{l}\% \text { of } \\
\text { Total }\end{array}$ & Count & $\begin{array}{l}\% \text { of } \\
\text { Total }\end{array}$ & Count & $\begin{array}{l}\% \text { of } \\
\text { Total }\end{array}$ & Count & $\begin{array}{l}\% \text { of } \\
\text { Total }\end{array}$ \\
\hline $\begin{array}{c}\text { HIS Increases } \\
\text { Administrative And } \\
\text { Healthcare } \\
\text { Efficiency } \\
\end{array}$ & 14 & $70.0 \%$ & 6 & $30.0 \%$ & 0 & $0.0 \%$ & 0 & $0.0 \%$ & 0 & $0.0 \%$ & 20 & $100 \%$ \\
\hline $\begin{array}{c}\text { His Reduces } \\
\text { Medication Errors }\end{array}$ & 6 & $30.0 \%$ & 7 & $35.0 \%$ & 5 & $25.0 \%$ & - & - & 2 & $10.0 \%$ & 20 & $100 \%$ \\
\hline $\begin{array}{c}\text { HIS offer statistical } \\
\text { data analysis \& } \\
\text { reports for decision } \\
\text { making }\end{array}$ & 8 & $40.0 \%$ & 12 & $60.0 \%$ & 0 & $0.0 \%$ & 0 & $0.0 \%$ & 0 & $0.0 \%$ & 20 & $100 \%$ \\
\hline $\begin{array}{c}\text { HIS Offer } \\
\text { Availability Of } \\
\text { Timely And Up-To- } \\
\text { Date Patient } \\
\text { Information }\end{array}$ & 13 & $65.0 \%$ & 7 & $35.0 \%$ & 0 & $0.0 \%$ & 0 & $0.0 \%$ & 0 & $0.0 \%$ & 20 & $100 \%$ \\
\hline
\end{tabular}

\subsubsection{Challenges of HIS Usage}

Again, four (4) items in the questionnaire were used to establish certain challenges associated with the use of HIS. Most of the respondents in both Hospitals (30\%) agree that HIS is affected by lack of computer literacy as shown in the table 5, with about $25 \%$ combined probability disagreeing with this claim. Most of the respondents (85\%) form Medanta and Apollo hospitals combined further disagreed that HIS is not user friendly in the delivery of health care services.
Respondents from both Hospitals were (36.8\%) generally disagree to the statement that HIS is affected by electrical power and poor backup facilities, with $26.3 \%$ from Apollo Hospitals remaining neutral in this regard. it explains the fact that backup facilities on the usage of HIS simply depends on the capabilities and the readiness of the Hospital to ensure continuous power supply. health care professionals further refuted the statement that their hospitals do not provide training needed to use HIS effectively, with a combined percentage of $68.4 \%$ disagreeing to that claim.

Table 5: Challenges of HIS Usage

\begin{tabular}{|c|c|c|c|c|c|c|c|c|c|c|c|c|}
\hline & \multicolumn{2}{|c|}{$\begin{array}{c}\text { STRONGLY } \\
\text { AGREE }\end{array}$} & \multicolumn{2}{|c|}{ AGREE } & \multicolumn{2}{|c|}{ Neutral } & \multicolumn{2}{|c|}{ Disagree } & \multicolumn{2}{|c|}{$\begin{array}{l}\text { Strongly } \\
\text { Disagree }\end{array}$} & \multicolumn{2}{|c|}{ Total } \\
\hline & Count & $\begin{array}{l}\% \text { of } \\
\text { Total }\end{array}$ & Count & $\begin{array}{l}\% \text { of } \\
\text { Total }\end{array}$ & Count & $\begin{array}{l}\% \text { of } \\
\text { Total }\end{array}$ & Count & $\begin{array}{l}\% \text { of } \\
\text { Total }\end{array}$ & Count & $\begin{array}{l}\% \text { of } \\
\text { Total }\end{array}$ & Count & $\begin{array}{l}\% \text { of } \\
\text { Total }\end{array}$ \\
\hline $\begin{array}{c}\text { HIS Is Affected By } \\
\text { Lack Of Computer } \\
\text { Literacy }\end{array}$ & 4 & $20.0 \%$ & 6 & $30.0 \%$ & 4 & $20.0 \%$ & 5 & $25.0 \%$ & 1 & $5.0 \%$ & 20 & $100 \%$ \\
\hline $\begin{array}{c}\text { HIS is not user } \\
\text { friendly }\end{array}$ & 1 & $5.0 \%$ & 1 & $5.0 \%$ & 1 & $5.0 \%$ & 8 & $40.0 \%$ & 9 & $45.0 \%$ & 20 & $100 \%$ \\
\hline $\begin{array}{l}\text { HIS is Affected By } \\
\text { Electrical Power \& } \\
\text { Poor Backup } \\
\text { Facilities }\end{array}$ & 1 & $5.3 \%$ & 3 & $15.8 \%$ & 6 & $31.6 \%$ & 7 & $36.8 \%$ & 2 & $10.5 \%$ & 19 & $100 \%$ \\
\hline $\begin{array}{l}\text { Organization Does } \\
\text { Not Provide } \\
\text { Training Needed To } \\
\text { Use HIS Effectively }\end{array}$ & 0 & $00.0 \%$ & 2 & $10.5 \%$ & 4 & $21.1 \%$ & 6 & $31.6 \%$ & 7 & $36.8 \%$ & 19 & $100 \%$ \\
\hline
\end{tabular}

\subsubsection{Management Challenges of HIS Usage}

There was total agreement by respondents (94.7\%) that HIS is very significant to management objectives, and a consensual disagreement $(47.4 \%)$ that the system only serves the technical needs of the hospital. Most respondents (52.6\%) remained neutral regarding the cost benefits of the adoption and maintenance of HIS in their facilities as indicated in table 6 . This confirms the perception that the cost of implementing HIS in hospitals still remains a top management silent decision. Table 7 shows some indication for both hospitals; Medenta and Apollo. 
Table 6: Management Challenges of HIS Usage

\begin{tabular}{|c|c|c|c|c|c|c|c|c|c|c|c|c|}
\hline & \multicolumn{2}{|c|}{$\begin{array}{c}\text { STRONGLY } \\
\text { AGREE }\end{array}$} & \multicolumn{2}{|c|}{ AGREE } & \multicolumn{2}{c|}{ Neutral } & \multicolumn{2}{c|}{ Disagree } & \multicolumn{2}{c|}{$\begin{array}{c}\text { Strongly } \\
\text { Disagree }\end{array}$} & \multicolumn{2}{c|}{ Total } \\
\cline { 2 - 13 } & Count & $\begin{array}{c}\% \text { of } \\
\text { Total }\end{array}$ & Count & $\begin{array}{c}\% \text { of } \\
\text { Total }\end{array}$ & Count & $\begin{array}{c}\% \text { of } \\
\text { Total }\end{array}$ & Count & $\begin{array}{c}\% \text { of } \\
\text { Total }\end{array}$ & Count & $\begin{array}{c}\% \text { of } \\
\text { Total }\end{array}$ & Count & $\begin{array}{c}\% \text { of } \\
\text { Total }\end{array}$ \\
\hline $\begin{array}{c}\text { HIS Is Very } \\
\text { Significant To } \\
\text { Management }\end{array}$ & 10 & $52.6 \%$ & 8 & $42.1 \%$ & 1 & $5.3 \%$ & 0 & $0.0 \%$ & 0 & $0.0 \%$ & 19 & $100 \%$ \\
\hline $\begin{array}{c}\text { HIS only serves } \\
\text { technical needs } \\
\text { of the } \\
\text { organization }\end{array}$ & 5 & $26.3 \%$ & 2 & $10.5 \%$ & 3 & $15.8 \%$ & 6 & $31.6 \%$ & 3 & $15.8 \%$ & 19 & $100 \%$ \\
\hline $\begin{array}{c}\text { HIS enhances } \\
\text { Decision Making } \\
\text { For } \\
\text { Management }\end{array}$ & 8 & $42.1 \%$ & 10 & $52.6 \%$ & 1 & $5.3 \%$ & 0 & $0.0 \%$ & 0 & $0.0 \%$ & 19 & $100 \%$ \\
\hline $\begin{array}{c}\text { HIS is very } \\
\text { costly to adopt } \\
\text { and maintain }\end{array}$ & 2 & $10.5 \%$ & 2 & $10.5 \%$ & 10 & $52.6 \%$ & 4 & $21.1 \%$ & 1 & $5.3 \%$ & 19 & $100 \%$ \\
\hline
\end{tabular}

Table 7: Management Challenges of HIS Usage by Hospital

\begin{tabular}{|c|c|c|c|c|c|}
\hline & & & \multicolumn{2}{|c|}{ HOSPITAL } & \multirow[b]{2}{*}{ Total } \\
\hline & & & $\begin{array}{l}\text { MEDANTA } \\
\text { HOSPITAL }\end{array}$ & $\begin{array}{c}\text { APOLLO } \\
\text { HOSPITAL }\end{array}$ & \\
\hline \multirow{10}{*}{$\begin{array}{l}\text { HIS is very costly to adopt and } \\
\text { maintain }\end{array}$} & Strongly Disagree & Count & 0 & 1 & 1 \\
\hline & & $\%$ of Total & $.0 \%$ & $5.3 \%$ & $5.3 \%$ \\
\hline & Disagree & Count & 3 & 1 & 4 \\
\hline & & $\%$ of Total & $15.8 \%$ & $5.3 \%$ & $21.1 \%$ \\
\hline & Neutral & Count & 5 & 5 & 10 \\
\hline & & $\%$ of Total & $26.3 \%$ & $26.3 \%$ & $52.6 \%$ \\
\hline & Agree & Count & 1 & 1 & 2 \\
\hline & & $\%$ of Total & $5.3 \%$ & $5.3 \%$ & $10.5 \%$ \\
\hline & Strongly Agree & Count & 0 & 2 & 2 \\
\hline & & $\%$ of Total & $.0 \%$ & $10.5 \%$ & $10.5 \%$ \\
\hline \multirow{2}{*}{\multicolumn{2}{|c|}{ Total }} & Count & 9 & 10 & 19 \\
\hline & & $\%$ of Total & $47.4 \%$ & $52.6 \%$ & $100.0 \%$ \\
\hline
\end{tabular}

\subsubsection{General Comments and Suggestions}

Participants were asked for further opportunities and challenges and their responses were summarized in table 7 . This was to establish the views of respondents on further challenges and opportunities. The few that responded to this question revealed that that HIS was the "Backbone Of Hospital Services" and technical challenges needed to be checked "periodically" to ensure smooth "process control." Some participants observed that frequent "change in management" in Hospitals or Organizations was a potential threat or challenge in the efficient and effective management of HIS, since each manager comes with new policies and procedures. Members suggested more training for technical users of the system to improve data entry procedures and enhance the speed of their work in the organization. Others credited the system for its ease of use and user friendly, and encouraged management to always update the software to always make it a more user friendly software.

\subsubsection{General Observations}

Medanta and Apollo Hospitals had very standard IT Departments that supported the management of the HIS, with marketing and other related staff doing the registration of clients. According to the users, perceived challenges such as system break downs, lack of infrastructure, and low computer literacy were not actually experienced in modern hospitals such as Apollo and Medanta. Both facilities had power backups and well-trained staff to manage the large numbers of clients. Other medically related IT systems were employed in health care delivery, without any interference with the HIS systems employed. the systems observed at both Medanta and Apollo Hospitals showed a network of electronic health data from the Registration Lounge through the Consulting rooms, the Pharmacy section, and then finally at the Medical records Department where data analysis and facility reports are generated for decision making.

A telemedicine sites at Medanta Hospital was also visited to observe telemedicine technologies and interactions between medical personnel, patients, and the mediating technologies. It 
was a great experience in witnessing a live session of Telemedicine procedures at Medanta hospital, where clients from other countries including Ghana and some other African countries consulted with Medical officers.

Table 8: Opportunities Or Challenges

\begin{tabular}{|c|c|c|c|c|c|}
\hline & & & & & \\
\hline & & & $\begin{array}{l}\text { MEDANTA } \\
\text { HOSPITAL }\end{array}$ & $\begin{array}{c}\text { APOLLO } \\
\text { HOSPITAL }\end{array}$ & Total \\
\hline $\begin{array}{c}\text { Any Other Opportunities Or } \\
\text { Challenges }\end{array}$ & System break downs & $\begin{array}{l}\text { Count } \\
\% \text { of Total } \\
\end{array}$ & $\begin{array}{c}8 \\
40.0 \% \\
\end{array}$ & $\begin{array}{c}8 \\
40.0 \% \\
\end{array}$ & $\begin{array}{c}16 \\
80.0 \% \\
\end{array}$ \\
\hline & $\begin{array}{c}\text { Backbone Of Hospital } \\
\text { Services }\end{array}$ & $\begin{array}{c}\text { Count } \\
\% \text { of Total }\end{array}$ & $\begin{array}{c}0 \\
.0 \% \\
\end{array}$ & $\begin{array}{c}1 \\
5.0 \% \\
\end{array}$ & $\begin{array}{c}1 \\
5.0 \% \\
\end{array}$ \\
\hline & Change In Management & $\begin{array}{c}\text { Count } \\
\% \text { of Total }\end{array}$ & $\begin{array}{c}1 \\
5.0 \%\end{array}$ & $\begin{array}{c}0 \\
.0 \%\end{array}$ & $\begin{array}{c}1 \\
5.0 \%\end{array}$ \\
\hline & Process Control & $\begin{array}{c}\text { Count } \\
\% \text { of Total }\end{array}$ & $\begin{array}{c}1 \\
5.0 \%\end{array}$ & $\begin{array}{c}0 \\
.0 \% \\
\end{array}$ & $\begin{array}{c}1 \\
5.0 \% \\
\end{array}$ \\
\hline & $\begin{array}{c}\text { Technical Challenges } \\
\text { Periodically }\end{array}$ & $\begin{array}{c}\text { Count } \\
\% \text { of Total }\end{array}$ & $\begin{array}{c}0 \\
.0 \%\end{array}$ & $\begin{array}{c}1 \\
5.0 \%\end{array}$ & $\begin{array}{c}1 \\
5.0 \%\end{array}$ \\
\hline Total & & $\begin{array}{c}\text { Count } \\
\% \text { of Total }\end{array}$ & $\begin{array}{c}10 \\
50.0 \%\end{array}$ & $\begin{array}{c}10 \\
50.0 \%\end{array}$ & $\begin{array}{c}20 \\
100.0 \%\end{array}$ \\
\hline Suggestions & Mobile Friendly & $\begin{array}{c}\text { Count } \\
\% \text { of Total }\end{array}$ & $\begin{array}{c}7 \\
35.0 \%\end{array}$ & $\begin{array}{c}5 \\
25.0 \%\end{array}$ & $\begin{array}{c}12 \\
60.0 \%\end{array}$ \\
\hline & Data Entry & $\begin{array}{c}\text { Count } \\
\% \text { of Total }\end{array}$ & $\begin{array}{c}3 \\
15.0 \%\end{array}$ & $\begin{array}{c}1 \\
5.0 \%\end{array}$ & $\begin{array}{c}4 \\
20.0 \%\end{array}$ \\
\hline & Ease of use & $\begin{array}{c}\text { Count } \\
\% \text { of Total }\end{array}$ & $\begin{array}{c}0 \\
.0 \%\end{array}$ & $\begin{array}{c}2 \\
10.0 \%\end{array}$ & $\begin{array}{c}2 \\
10.0 \%\end{array}$ \\
\hline & User Friendly & $\begin{array}{c}\text { Count } \\
\% \text { of Total }\end{array}$ & $\begin{array}{c}0 \\
.0 \%\end{array}$ & $\begin{array}{c}2 \\
10.0 \%\end{array}$ & $\begin{array}{c}2 \\
10.0 \%\end{array}$ \\
\hline Total & & $\begin{array}{c}\text { Count } \\
\text { \% of Total }\end{array}$ & $\begin{array}{c}10 \\
50.0 \%\end{array}$ & $\begin{array}{c}10 \\
50.0 \%\end{array}$ & $\begin{array}{c}20 \\
100.0 \%\end{array}$ \\
\hline
\end{tabular}

\section{CONCLUSION}

The general objective of the research was to explore the opportunities and challenges regarding the use of HIS in Indian hospitals and to recommend guiding principles that could promote the use of HIS for quality healthcare delivery in Africa and especially in Ghana. Notwithstanding India's dominance as the center of Information Technology (IT) powered by a vast pool of skilled manpower, some renowned Hospitals like J.N Medical College, Firoz Specialist Hospital, Mithraj Hospital Aligarh, and the Aligarh University Health Services still lagged tremendously behind in the adoption of HIS in health care delivery. However, as expected, Apollo and Medanta Hospitals in New Delhi used systems like "MEDMANTRA" and "ISOFT" as their HIS for health care delivery and for decision making. These e-health systems were installed with the goal of enabling physicians and caregivers to employ technology for better care delivery. they were also to set-up a mechanism for prompt collection, collation and release of valid data for management decisions, and proper disposal of dormant records.

The research ascertained that HIS offer tremendous opportunities such as; growing administrative healthcare efficiency, dipping medication errors, making statistical analysis, and offering availability of timely and up-to-date patient information in health care management. Except for privately owned modern hospitals, most patient records at government hospitals in Aligarh are paper based and they are yet to adopt modern HIS in their facilities. Lack of supporting infrastructure and coordination were some of the challenges disclosed by personnel of these institutions in Aligarh especially. Findings revealed other challenges such as low computer literacy among some government staff, and very large patient size at the government hospitals. Meanwhile the information gotten from authorities was that efforts were underway by the Ministry of Health and Family to computerize basic information systems at the top public tertiary hospitals in India. Telemedicine sites at Medanta Hospitals were also visited to observe telemedicine technologies and interactions between medical personnel, patients, and the mediating technologies. This served as an added technology in reaching out to patients from far and wide. The live session experience of the Telemedicine of Medanta hospital showed the efficacy of this technology and how easy that could be adopted in Ghana and other African counties. Hardware systems such as Polycom HDx 7000 codec video conferencing systems supported with two monitors and high speed internet package were the set-ups 
needed to have a functioning telemedicine procedure in a hospital. In consistent with[19][16], I realized that telemedicine really means "healing at a distance" and it actually signifies the use of ICT to provide or support clinical care at a distance and to improve patient outcomes by increasing access to care and medical information [4].

\section{REFERENCES}

[1] Z. Darulis, Use and Perceptions of Lithuanian Computerized Health Information System Zilvinas Darulis Nordic School of Public Health Master of Public Health. 2005.

[2] M. Kay, J. Santos, and M. Takane, "Telemedicine: Opportunities and developments in Member States," Observatory, vol. 2, p. 96, 2010, doi: 10.4258/hir.2012.18.2.153.

[3] "Health Metrics Network Ghana (2005) Health Information System Profile and Assessment Draft, Health Metrics Network Ghana health information system: Profile and assessment.," p. 2005, 2005.

[4] E. Goorman and M. Berg, "Modelling nursing activities: electronic patient records and their discontents," Nurs. Inq., vol. 7, no. 1, p. 3-9., 2000.

[5] E. Ammenwerth, C. Iller, and C. Mahler, "IT-adoption and the interaction of task, technology and individuals: A fit framework and a case study," BMC Med. Inform. Decis. Mak., vol. 6, pp. 1-13, 2006, doi: 10.1186/14726947-6-3.

[6] F. Anwar and A. Shamim, "Barriers in Adoption of Health Information Technology in Developing Societies," Int. J. Adv. Comput. Sci. Appl., vol. 2, no. 8, pp. 40-45, 2011, doi: 10.14569/ijacsa.2011.020808.

[7] Y. Hayajneh, W. Hayajneh, and I. Matalka, "Extent of Use, Perceptions, and Knowledge of a Hospital Information System by Staff Physicians," ..., no. March, 2006, [Online]. Available: http://cases.hayajneh.org/research/Extent_of_Use_.pdf.

[8] J. Braa, O. Hanseth, A. Heywood, W. Mohammed, and V. Shaw, "Developing health information systems in developing countries: The flexible standards strategy," MIS Q. Manag. Inf. Syst., vol. 31, no. 2, pp. 381-402, 2007, doi: $10.2307 / 25148796$.

[9] G. W. Odhiambo-Otieno, "Evaluation criteria for district health management information systems: Lessons from the Ministry of Health, Kenya," Int. J. Med. Inform., vol. 74, no. 1, pp. 31-38, 2005, doi: 10.1016/j.ijmedinf.2004.09.003.

[10] M. Smith, S. Madon, A. Anifalaje, M. Lazarro-Malecela, and E. Michael, "Integrated Health Information Systems in Tanzania: Experience and Challenges," Electron. J. Inf. Syst. Dev. Ctries., vol. 33, no. 1, pp. 1-21, 2008, doi: 10.1002/j.1681-4835.2008.tb00227.x.

[11] N. Archangel, T. M. Informatiekunde, P. Business, I. Systems, and U. Van Amsterdam, "The critical issues affecting the introduction of Health Management Information Systems in developing countries in Africa," no. October, 2007.

[12] DHIS2, "DHIS 2 Documentation Team (2014), DHIS 2 User Manual, Dhis2 Implementation Guide, 1179 Version 2," Manual, pp. 1-390, 2016.

[13] “About Norad,” 2020. https://norad.no/en/front/aboutnorad/ (accessed Jul. 12, 2020).

[14] E. M. Strehle and N. Shabde, "One hundred years of telemedicine: does this new technology have a place in paediatrics?," Arch. Dis. Child., vol. 91, no. 12, p. 956 LP-959, Dec. 2006, doi: 10.1136/adc.2006.099622.

[15] M. Kay, J. Santos, and M. Takane, "Telemedicine: Opportunities and developments in Member States," Observatory, vol. 2, p. 96, 2010, doi: 10.4258/hir.2012.18.2.153.

[16] C. J. Ghia, A. S. Patil, J. K. Ved, and R. K. Jha, "Benefits of Telemedicine and Barriers to its Effective Implementation in Rural India: A Multicentric ESurvey," Indian Medical Gazette, no. January. pp. 1-7, 2013.

[17] T. E. Norris et al., "Low-bandwidth, low-cost telemedicine consultations in rural family practice," $J$. Am. Board Fam. Pract., vol. 15, no. 2, pp. 123-127, 2002.

[18] "Home," 1999. https://www.medmantra.com/ (accessed Jun. 13, 2020).

[19] E. M. Strehle and N. Shabde, "One hundred years of telemedicine: does this new technology have a place in paediatrics?," Arch. Dis. Child., vol. 91, no. 12, p. 956 LP-959, Dec. 2006, doi: 10.1136/adc.2006.099622. 